\title{
Pengaruh Kompetensi Karyawan Tingkat Struktural dan Persepsi Bawahannya Terhadap Unit Performance Pada Departemen Produksi PT Aerofood Indonesia
}

\author{
Catherine Aprimanti Secundina, Agung Nugroho* \\ Program Studi Magister Manajemen Fakultas Ekonomi dan Bisnis Universitas Indonesia \\ *Corresponding author : a.nugroho@ui.ac.id
}

\begin{abstract}
Abstrak
Penelitian ini bertujuan untuk melihat apakah ada perbedaan antara kompetensi karyawan tingkat struktural dan persepsi bawahannya serta melihat pengaruh antara kompetensi karyawan tingkat struktural dan persepsi bawahannya terhadap kinerja unit produksi di PT Aerofood Indonesia. Penelitian dilakukan di PT Aerofood Indonesia pada 17 karyawan tingkat struktural di Departemen Produksi dan 85 karyawan yang merupakan bawahan dari masing-masing karyawan tingkat struktural tersebut. Pengukuran kompetensi menggunakan Sandwith's Competency Domain Model yang terbagi menjadi 5 domain, yaitu conceptual/creative competencies, interpersonal competencies, leadership competencies, administrative domain dan technical domain. Pengolahan data menggunakan uji t dan analisis regresi dengan dibantu software SPSS. Hasil dari penelitian ini menunjukkan bahwa tidak ada perbedaan nilai antara kompetensi karyawan tingkat struktural dan persepsi bawahannya. Selain itu, dari hasil analisis regresi, dapat disimpulkan bahwa peran variabel independen berupa gap kompetensi berpengaruh terhadap pencapaian unit performance di Departemen Produksi PT Aerofood Indonesia yang ditunjukkan dengan nilai koefisien R sebesar 0,970.
\end{abstract}

Kata Kunci: Kompetensi Karyawan, Tingkat Struktural, Persepsi, Unit Performance

\section{PENDAHULUAN}

Situasi ekonomi yang tidak menentu saat ini membuat persaingan antar perusahaan semakin ketat, termasuk bajakmembajak tenaga profesional. Dalam menghadapi fenomena tersebut, perusahaan memerlukan employee retention yang diikuti oleh employee engagement yang baik. Persaingan tersebut tidak hanya untuk merebut pelanggan tetapi juga untuk merebut karyawankaryawan terbaik. Sehingga karyawan yang unggul perlu dipertahankan oleh perusahaan. Oleh karena itu, wajib hukumnya jika setiap karyawan harus ditingkatkan kompetensinya baik kompetensi intinya, fungsional maupun manajerialnya melalui program pengembangan yang terstruktur.

Hasil penelitian yang dilakukan oleh Hewitt Associates, 2003-2006 (dalam Permana dkk., 2011), terhadap para CEO tentang faktor yang paling berpengaruh pada hasil bisnis menunjukkan angka sebagai berikut: talent acquisition \& retention (98\%); kualitas kepemimpinan (89\%) dan keterikatan karyawan (employee 
engagement) (84\%). Dari hasil tersebut menunjukkan bahwa talent acquisition \& retention merupakan faktor yang paling berpengaruh terhadap hasil bisnis. Dengan demikian, efektifitas talent management pada proses mempertahankan karyawankaryawan terbaik menjadi faktor yang menentukan.

Berger \& Berger (2008) menyebutkan bahwa terdapat 3 komponen pembentuk Manajemen Talenta, yaitu Kompetensi, Manajemen Kinerja dan Rencana Jalur Karier. Tahap awal untuk bisa memilih talenta adalah dengan menentukan kompetensi yang diinginkan perusahaan. Kompetensi sangat ditekankan karena perusahaan membutuhkan para pemimpin yang memiliki nilai-nilai dan budaya yang selaras dengan nilai-nilai dan budaya perusahaan. Proses penentuan kompentensi dan potensi setiap karyawan berdasarkan definisi dan skala pengukuran yang ditetapkan. Kompetensi inti (core competencies) merupakan perilaku / keterampilan / nilai-nilai yang diharapkan diwujudkan oleh para karyawan karena sangat penting bagi karyawan untuk mencapai keberhasilan yang sangat diperlukan bagi keberhasilan organisasi (Berger \& Berger, 2008).

Setiap organisasi memiliki kompetensi yang bergantung pada kerangka visi organisasi itu sendiri.
Kompetensi inti yang ada pada setiap organisasi seharusnya mempunyai sifat khas bagi organisasi itu sendiri (Dewi, 2012). Kompetensi inti tersebut agar dapat digunakan secara efektif, maka dipastikan harus mampu menjawab tantangan dari para pesaingnya atau disebut juga competitive advantage. Dengan demikian, apabila organisasi mulai mengkonsentrasikan diri pada kompetensi inti organisasi, maka organisasi tersebut harus cepat memberikan perhatian lebih banyak dan berfokus pada kompetensi dari anggota atau karyawannya. Sebab, salah satu variabel pembentuk kompetensi inti organisasi yang baik adalah dari kompetensi individu karyawannya itu sendiri. Sandwith (1993) mengembangkan Competency Domain Model, yang terdiri dari (1) conceptual-creative competencies, (2) interpersonal competencies, leadership competencies, administrative domain dan (5) technical domain.

Penelitian ini bertujuan untuk mengukur sejauh mana kompetensi yang ditetapkan oleh Sandwith (1993) dalam meningkatkan performance profesional di sektor hospitality \& food. Pergantian lingkungan bisnis yang cepat, termasuk ketatnya pasar tenaga kerja, kuatnya kompetisi, dan permintaan pelanggan yang beragam, menjadi tantangan bagi industri 
yang ada di sektor hospitality \& food saat ini (Cho, Woods, Jang \& Erdem, 2006). Pada dasarnya, 'Talent' di mata masyarakat adalah yang berkaitan dengan orang-orang muda (Sabuncu \& Karacay, 2016). Penelitian yang dilakukan oleh Pratten (2003) menyebutkan bahwa 30\% pekerja yang ada di industri catering berumur kurang dari 24 tahun, dan angka ini ada di $13 \%$ industri sejenis. Berdasarkan penelitian tersebut, dapat diasumsikan bahwa di industri hospitality ada potensi talent yang tinggi.

PT Aerofood Indonesia (Aerofood ACS) merupakan salah satu anak perusahaan dari PT Aerowisata Indonesia (Garuda Indonesia Group) yang bergerak dalam bidang penyedia airline catering bertaraf internasional. Bisnis PT Aerofood Indonesia terbagi menjadi 3 , yaitu InFlight Catering Services, Industrial Catering dan In-Flight Service Total Solution. Salah satu faktor keberhasilan dalam sebuah industri adalah manajemen produksi, karena manajemen produksi merupakan proses pencapaian dan pengutilisasian sumber daya-sumber daya untuk memproduksi atau menghasilkan barang-barang atau jasa-jasa yang berguna sebagai usaha untuk mencapai tujuan dan sasaran organisasi (Assauri, 1993).

Penelitian ini menyoroti faktor kualitas manusia terutama kompetensi yang dimiliki oleh para profesional (karyawan dengan jabatan level struktural) catering service di departemen produksi yang diukur dengan Sandwith's Competency Domain Model untuk meningkatkan performance unit tersebut di bidang catering service. Objek yang akan menjadi sasaran penelitian ini adalah karyawan dengan jabatan level struktural dan karyawan yang merupakan bawahannya sebagai objek yang dianggap merasakan secara langsung perilaku para profesional ini. Dengan dilakukan penelitian ini, diharapkan dapat menjadi masukan bagi perusahaan untuk memberikan usulan pelatihan yang dianggap cukup penting dalam meningkatkan kinerja unit bisnis maupun kinerja organisasi.

\section{KAJIAN PUSTAKA}

Kompetensi. Kompetensi adalah sebuah karakteristik yang mendasari seseorang yang secara begitu saja berhubungan dengan kriteria efektif yang direkomendasikan dan/atau performa utama dalam sebuah jabatan (pekerjaan) atau keadaan (Spencer, 1993). Sedangkan, Berger \& Berger (2008) menyebutkan bahwa kompetensi adalah karakteristik (atau kombinasi beberapa karakteristik) yang dapat diukur secara andal dan relatif bertahan lama (stabil) yang dimiliki seseorang, tim atau organisasi yang 
menyebabkan dan secara statistik dapat memprediksi kriteria (ukuran) tingkat kinerja.

Model Kompetensi. Model kompetensi menetapkan keterampilan yang diperlukan bagi keberhasilan suatu organisasi. Ada banyak cara untuk mengembangkan model kompetensi dan memanfaatkannya untuk organisasi (Berger \& Berger, 2008). Katz (1955) dalam Koenigsfeld et al. (2011) percaya bahwa keterampilan seorang administrator didasarkan pada tiga keterampilan domain: technical skills, human skills, dan conceptual skills. Technical skills mengacu pada kompetensi yang dibutuhkan untuk melakukan pekerjaan (Meyer \& Semark, 1996 dalam Koenigsfeld et al., 2011). Human skills melibatkan kemampuan eksekutif untuk bekerja secara efektif sebagai anggota tim bahwa ia memimpin (Katz, 1955 dalam Koenigsfeld et al.,2011). Sedangkan menurut Katz juga, conceptual skills ditandai dengan strategi dan keputusan kebijakan pemimpin perusahaan.

Model kompetensi yang digunakan pada penelitian ini adalah penelitian yang dikembangkan oleh Sandwith (1993) yang berdasarkan domain-domain atau segmensegmen dari pekerjaan atau tugas. Dengan mengembangkan model ini, Sandwith memperluas model kompetensi yang telah dikembangkan oleh Katz (1955) untuk melibatkan domain leadership, administrative dan interpersonal. Model kompetensi yang dikembangkan oleh Sandwith (1993) telah banyak digunakan untuk mengidentifikasi dan mengembangkan set kompetensi dalam industri hospitality.

\section{Sandwith's Competency Domain}

Model. Tas et al. (1996) mengaplikasikan Sandwith's Competency Domain Model ke 19 kompetensi manajemen properti yang digunakan untuk hotel management trainee. Kay \& Russete (2000) menguji hubungan pekerjaan dan kompetensi para manajer di bidang hospitality dengan menggunakan Sandwith's Competency Domain Model. Kemudian Tsai et al. (2006) juga menggunakan Sandwith's Competency Domain Model sebagai kerangka untuk menguji kompetensi untuk entry-level para trainee di lodging management. Dan yang terbaru, Hu (2010) menggunakan Sandwith's Competency Domain Model dalam penelitiannya mengenai kompetensi inti dalam pengembangan kuliner yang inovatif.

Domain yang pertama adalah conceptual-creative domain. Aspek konseptual disini mengaju pada keahlian kognitif yang berkaitan dengan pemahaman elemen-elemen penting dari pekerjaan. Keterampilan konseptual yang 
paling umum adalah memahami satu peran di organisasi dan bagaimana hal tersebut berhubungan dengan yang lainnya. Sedangkan dimensi kreatif ditambahkan ke keahlian konseptual untuk lebih sering merefleksikan pemahaman fungsi otak dan pemikiran kreatif.

Domain yang kedua adalah leadership atau kepemimpinan yang menyediakan hubungan stratejik antara domain conceptual dengan domain yang lain. Ketika domain conceptual / creative fokus pada pemahaman fenomena dan menciptakan ide untuk tindakan, itu adalah kepemimpinan yang mengubah pemikiran menjadi tindakan yang produktif. Domain yang ketiga adalah interpersonal competencies. Kompetensi interpersonal berfokus pada keahlian untuk berinteraksi secara efektif dengan orang lain.

Domain yang keempat adalah administrative domain. Administrative domain berevolusi sebagai cara untuk mengatasi daerah-daerah aktifitas di organisasi yang terletak di antara interpersonal domain dan technical domain. Kata administrative disini mengacu pada aspek manajemen personalia dan manajemen finansial di organisasi, dimana hal tersebut berhubungan dengan operasi teknis dalam organisasi. Adanya pemisahan antara administrative domain dan technical domain dilakukan karena technical domain untuk departemen yang berbeda dalam organisasi mungkin lebih unik, walaupun dengan sedikit kesamaan dan sistem administratif untuk bagian personal dan finansial akan selalu konsisten untuk semua departemen. Pelatihan yang bersifat teknis akan dirancang berbeda untuk setiap departemen, walaupun pelatihan yang bersifat administratif akan sama untuk semua departemen.

Domain yang terakhir adalah technical domain. Area aktifitas ini lebih mudah untuk diingat di hampir semua organisasi, domain ini mengacu pada pekerjaan aktual yang dilakukan organisasi.

Persepsi. Persepsi adalah integrasi dan interpretasi seseorang terhadap stimulus (Galotti, 2014). Stimulus yang dimaksud bukan hanya rangsangan dari luar dirinya, namun juga rangsangan dari dalam dirinya, seperti suasana hati, kondisi fisik, dan emosi seseorang (Otara, 2011).

Dalam pekerjaan dan organisasi, persepsi merupakan suatu yang sangat vital. Salah satu penyebab adanya konflik di dalam organisasi adalah perbedaan persepsi (Quick \& Nelson, 2009). Ada halhal penting yang harus dipertimbangkan dalam memahami persepsi di dalam organisasi (Otara, 2011), yaitu (1) Persepsi objektif adalah suatu yang mustahil, (2) 
Setiap individu memiliki cara pandang yang berbeda terhadap stimulasi yang sama, bergantung pada pengalaman dirinya, yang kemudian akan mempengaruhi perilaku nampaknya, (3) Hal yang sama pentingnya seperti pengalaman dalam persepsi seseorang adalah nilai, kepercayaan, dan sikap individu tersebut terhadap stimulasi yang ada, dan (4) Persepsi seseorang akan mempengaruhi tingkat prioritas dalam hidupnya.

Performance. Kinerja merupakan hasil pekerjaan yang mempunyai hubungan kuat dengan tujuan strategis organisasi, kepuasan konsumen, dan memberikan kontribusi pada ekonomi (Armstrong dan Baron, 1998:15). Sedangkan manajemen kinerja adalah proses komunikasi yang dilakukan secara terus-menerus dalam kemitraan antara karyawan dengan atasan langsungnya (Bacal, 1999:4). Berbeda dengan Bacal yang menekankan pada proses komunikasi, Armstrong (2009) lebih melihat manajemen kinerja sebagai sarana untuk mendapatkan hasil yang lebih baik dari organisasi, tim, dan individu dengan cara memahami dan mengelola kinerja dalam suatu kerangka tujuan, standar, dan persyaratan-persyaratan atribut yang disepakati.

Menurut Parmenter (2010), terdapat empat ukuran untuk menilai kinerja, yaitu
(1) indikator hasil (Result Indicator / RI), (2) indikator hasil utama (Key Result Indicator / KRI), (3) indikator kinerja (Performance Indicator), dan (4) indikator kinerja utama (Key Performance Indicator / KPI).

\section{METODE PENELITIAN}

Model yang digunakan pada penelitian ini mengadaptasi terhadap model penelitian yang dirumuskan oleh Koenigsfeld et al. (2011), namun telah diolah kembali oleh peneliti sebagai penyesuaian terkait metode penelitian. Berikut model yang digunakan pada penelitian ini yaitu:

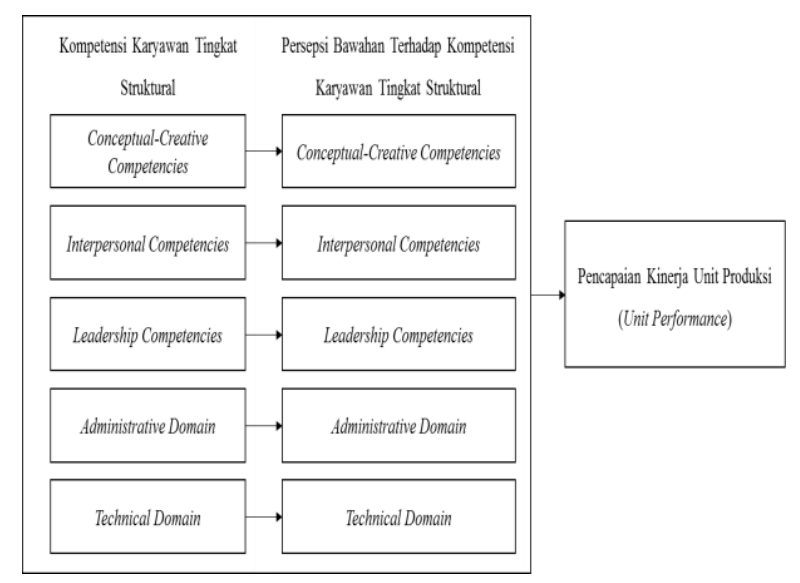

Gambar 1. Model Penelitian

Hipotesis penelitian yang akan diuji dalam penelitian ini adalah sebagai berikut:

Tabel 1. Hipotesis Penelitian 
creative competencies yang dimiliki atasannya

\begin{tabular}{|c|c|}
\hline H2 & $\begin{array}{l}\text { Interpersonal competencies yang dimiliki } \\
\text { atasan memiliki perbedaan dengan persepsi } \\
\text { bawahannya terkait } \begin{array}{l}\text { interpersonal } \\
\text { competencies yang dimiliki atasannya }\end{array}\end{array}$ \\
\hline H3 & $\begin{array}{l}\text { Leadership competencies yang dimiliki atasan } \\
\text { memiliki perbedaan dengan persepsi } \\
\text { bawahannya terkait leadership competencies } \\
\text { yang dimiliki atasannya }\end{array}$ \\
\hline H4 & $\begin{array}{l}\text { Administrative domain yang dimiliki atasan } \\
\text { memiliki perbedaan dengan persepsi } \\
\text { bawahannya terkait administrative domain } \\
\text { yang dimiliki atasannya }\end{array}$ \\
\hline H5 & $\begin{array}{l}\text { Technical domain yang dimiliki atasan } \\
\text { memiliki perbedaan dengan persepsi } \\
\text { bawahannya terkait technical domain yang } \\
\text { dimiliki atasannya }\end{array}$ \\
\hline H6 & $\begin{array}{l}\text { Kompetensi yang dimiliki atasan dan persepsi } \\
\text { bawahannya memiliki pengaruh terhadap unit } \\
\text { performance }\end{array}$ \\
\hline
\end{tabular}

Pengumpulan data yang digunakan dalam penelitian ini terdiri dari data primer dan data sekunder. Data primer merupakan data yang diperoleh langsung melalui narasumber aslinya. Sedangkan data sekunder merupakan data yang diperoleh dari sumber lain selain sumber asli yang dapat digunakan sebagai data untuk pelaksanaan penelitian ini. Berikut merupakan jenis dan sumber data yang dikumpulkan dari penelitian ini:

1) Data primer, yang meliputi jumlah karyawan di Departemen Produksi PT Aerofood Indonesia cabang Jakarta. Data primer lainnya yaitu jawaban karyawan yang dijadikan responden dari penelitian ini melalui instrumen penelitian berupa kuesioner. Kuesioner disebar kepada seluruh karyawan di Departemen Produksi PT
Aerofood Indonesia cabang Jakarta dengan pengelompokan menjadi dua yaitu karyawan tingkat struktural dan bawahannya.

2) Data sekunder, meliputi profil perusahaan dan aktivitas bisnisnya yang dapat diperoleh dari laporan tahunan yang diterbitkan perusahaan. Data lainnya yaitu informasi perusahaan yang dapat diperoleh melalui buku, internet, serta data lainnya.

Populasi yang digunakan pada penelitian ini terbagi menjadi dua yaitu karyawan tingkat struktural di Departemen Produksi PT Aerofood Indonesia cabang Jakarta dan bawahannya. Pemilihan kantor cabang Jakarta yang juga merupakan kantor pusat didasari karena kantor pusat dianggap mewakili kantor-kantor cabang lain yang tersebar di seluruh Indonesia. Selain itu posisi-posisi strategis perusahaan mayoritas berada pada kantor pusat yang mana penerapan strategi perusahaan secara keseluruhan berawal dari kantor pusat. Kantor pusat juga menjadi cerminan berjalannya kinerja organisasi secara keseluruhan.

Kuesioner dimensi kompetensi yang digunakan dalam penelitian ini yaitu kuesioner yang dilakukan oleh Koenigsfeld et al. (2011). Kuesioner ini mengalami penyesuaian menjadi lingkup organisasi 
dan industri catering service dari yang sebelumnya lingkup private club industri. Kuesioner ini menggunakan skala Likert dengan 6 skala untuk mengukur tingkat frekuensi penggunaannya yaitu skala 1 menyatakan Tidak Pernah Sama Sekali (TP), skala 2 menyatakan Sangat Jarang (SJ), skala 3 menyatakan Jarang (J), skala 4 menyatakan Kadang (K), skala 5 menyatakan Sering (S), dan skala 6 menyatakan Sangat Sering (SS).

Pengujian validitas dilakukan dengan menggunakan pearson correlation product moment yaitu dengan cara menghitung korelasi antara skor masing-masing butir pernyataan dengan total skor (Ghozali, 2001). Kriteria yang digunakan valid atau tidak valid adalah jika korelasi antara skor masing-masing butir pernyataan dengan total skor mempunyai tingkat signifikansi di bawah 0,05 atau sig. $<0,05$ maka butir pernyataan tersebut dapat dikatakan valid, dan jika korelasi skor masing-masing butir pernyataan dengan total skor mempunyai tingkat signifikansi di atas 0,05 atau sig. > 0,05 maka butir pernyataan tersebut dikatakan tidak valid.

Penelitian ini menggunakan metode analisis data regresi linier berganda dengan bantuan program statistik dalam teknik pengolahan data, yaitu menggunakan program piranti lunak Statistic Product and Service Solution (SPSS). Data diolah untuk mendapatkan informasi deskriptif dan analisis model penelitian. Analisis deskriptif dilakukan untuk mendapat gambaran jawaban responden secara deskriptif. Analisis model penelitian dilakukan untuk menguji model dan hipotesis penelitian. Dalam analisis model penelitian digunakan analisis korelasi berganda (multiple correlation) untuk mencari besarnya hubungan dan kontribusi dua variabel bebas atau lebih secara simultan (bersama-sama) dengan variabel terikat (Riduwan \& Sunarto, 2007).

\section{HASIL DAN PEMBAHASAN}

Hasil Pre-Test. Pre-test dilakukan terhadap 30 responden dengan kriteria memiliki bisnis catering atau sedang bekerja di industri catering service. Kuesioner yang diberikan untuk mewakili karyawan tingkat struktural diberikan kepada responden yang memiliki bisnis catering sejumlah 15 dan kuesioner yang diberikan untuk mewakili bawahan dalam menjawab persepsi bawahan diberikan kepada orang yang sedang bekerja di industri catering service sejumlah 15.

Instrumen penelitian perlu diukur agar mengetahui apakah instrumen tersebut valid atau tidak. Validitas yaitu tingkat akurasi pengukuran pada alat ukur untuk mengukur sesuatu yang diukur (Heirs et al, 2010). Instrumen alat ukur dinyatakan 
valid apabila item pernyataan yang terdapat pada instrumen tersebut memiliki makna dari jawaban yang diberikan responden. Dalam uji validitas ini menggunakan uji kecukupan sampling melalui Kaiser-Meyer-Olkin Measure of Sampling Adequacy (KMO-MSA), dan component matrix. Jika nilai KMO yang diperoleh pada masing-masing kuesioner melebihi nilai 0.5 menunjukkan bahwa sampling yang diambil telah tercukupi (Ghozali, 2005). Jika pada skor loading factor component matrix lebih dari sama 0.5 menunjukkan bahwa instrumen yang digunakan dapat dinyatakan valid (Hair, 2010).

Dari hasil pengujian dapat disimpulkan bahwa item dimensi pada dimensi conceptual/creative competencies, interpersonal competencies, leadership competencies, administrative domain dan technical domain dinyatakan valid dan reliabel. Setiap nilai KMO dan nilai Cronbach Alpha bernilai di atas 0.5, hasil tersebut menyatakan bahwa sampling data yang telah dilakukan telah tercukupi dalam kuesioner dan kuesioner yang telah disebar dapat dinyatakan valid dan reliabel.

Karakteristik Sampel. Penelitian dilakukan dengan melakukan penyebaran kuesioner kepada 102 karyawan yang terbagi menjadi 17 karyawan yang merupakan karyawan Departemen
Produksi PT Aerofood Indonesia cabang Jakarta tingkat struktural (Sous Chef, Head, Executive Sous Chef, dll) dan 85 karyawan PT Aerofood yang merupakan bawahan dari karyawan tingkat struktural tersebut. Penyebaran kuesioner dilakukan dengan cara memberikan kuesioner kepada masing-masing responden. Kendala dalam menyebarkan kuesioner adalah responden yang merupakan karyawan di departemen produksi tidak mudah untuk ditemui karena tempat kerja mereka berada di area yang terbatas untuk melarang sembarangan orang untuk masuk (kecuali karyawan bagian produksi).

Analisis Deskriptif. Berdasarkan hasil analisis deskriptif variabel kompetensi karyawan tingkat struktural dapat disimpulkan bahwa rata-rata dari responden berada di kategori sering yaitu di angka 4,68. Sebanyak 48 pertanyaan berada di kategori sering, 7 pertanyaan di kategori sangat sering, 4 pertanyaan di kategori jarang dan 10 pertanyaan di kategori kadang. Hal ini menunjukkan bahwa karyawan di tingkat struktural menilai dirinya mempunyai kompetensi yang cukup tinggi berdasarkan jawaban yang didominasi oleh kategori sering pada setiap butir pertanyaan.

Hasil analisis deskriptif variabel persepsi bawahannya menunjukkan ratarata hasil responden bawahannya berada di 
kategori sering dengan angka 4,55.

Sebanyak 58 pertanyaan berada di kategori sering dan sebanyak 18 pertanyaan berada di kategori kadang. Hal ini menunjukkan bahwa bawahan menilai para atasannya yaitu karyawan tingkat struktural memiliki kompetensi yang cukup tinggi berdasarkan jawaban yang didominasi dengan hasil di kategori sering.

Secara grafis data capaian kinerja operasional masing-masing unit dapat digambarkan sebagai berikut:

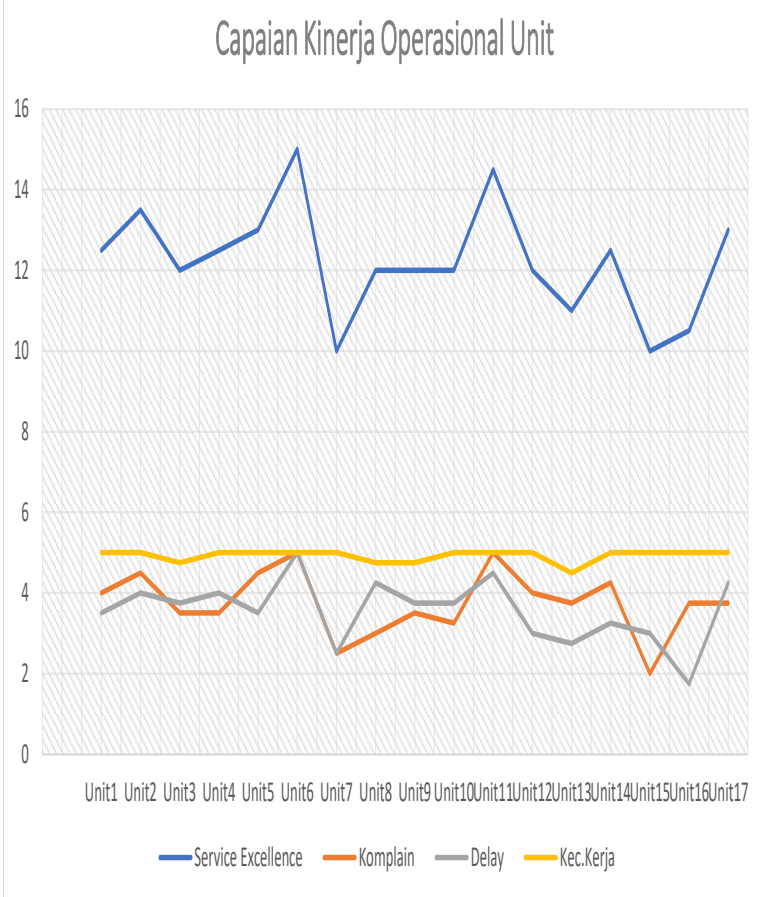

Gambar 2. Capaian Kinerja Service Excellence Masing-masing Unit

Hasil Uji Hipotesis. Hasil uji beda variabel independen yang diperoleh berdasarkan pengolahan SPSS adalah sebagai berikut:
Tabel 2. Hasil Uji Beda Variabel Independen

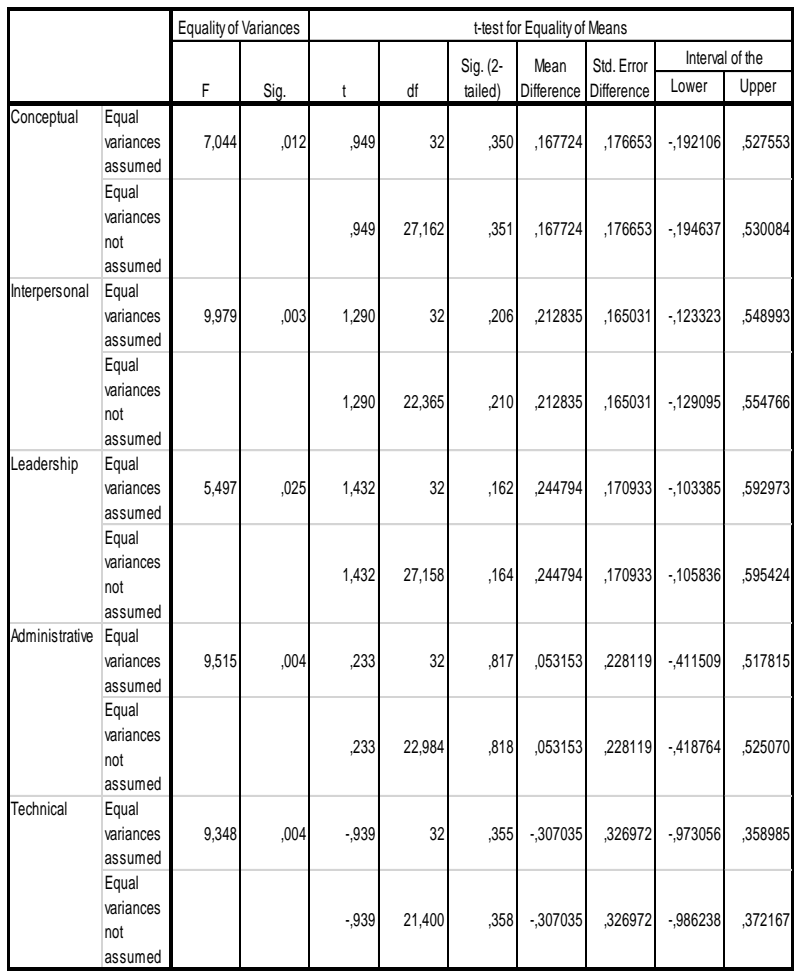

Hasil kesamaan varian (homogenitas) dengan $\mathrm{F}$ test (Levene,s Test) berdasarkan tabel di atas, dapat diketahui bahwa untuk seluruh variabel independen Sig: $\mathrm{P}$ value $<0,05$. Hal ini berarti bahwa ada perbedaan varians pada data kompetensi karyawan tingkat atasan dengan data persepsi bawahannya. Dengan ini penggunaan uji t menggunakan equal variance not assumed (diasumsikan kedua varian berbeda).

Dari tabel di atas didapat nilai $\mathrm{t}$ hitung (equal variance not assumed) adalah $\quad 0,949 \quad$ (conceptual); 1,290 (interpersonal); 1,432 (leadership); 0,233 (administrative); dan -0,939 (technical). Sedangkan dari Tabel distribusi t pada 
$\alpha=5 \%$ dengan derajat kebebasan (df) 32, hasil diperoleh untuk t tabel sebesar 2,037.

Berdasarkan pengujian bahwa $-\mathrm{t}$ tabel $<\mathrm{t}$ hitung $<\mathrm{t}$ tabel maka Ho diterima (Ho: Tidak ada perbedaan antara rata-rata kompetensi karyawan tingkat struktural dan persepsi bawahannya). Dengan demikian berarti bahwa tidak ada perbedaan antara rata-rata kompetensi karyawan tingkat atasan dengan rata-rata persepsi bawahan untuk seluruh variabel independen: conceptual, interpersonal, leadership, administrative, dan technical domain.

Uji F dilakukan untuk mengetahui pengaruh variabel independen conceptual/creative, interpersonal, leadership, administrative, dan technical domain secara bersama-sama atau simultan terhadap variabel capaian kinerja operasional unit. Hasil pengujian pengaruh simultan dapat dilihat pada Tabel 3. berikut ini.

Tabel 3. Uji Simultan Antara Variabel Independen Dengan Variabel Dependen ANOVA $^{a}$

\begin{tabular}{|rl|r|r|r|r|c|}
\hline \multicolumn{1}{|l|}{} & \multicolumn{1}{|c|}{$\begin{array}{c}\text { Sum of } \\
\text { Squares }\end{array}$} & \multicolumn{1}{c|}{ df } & Mean Square & \multicolumn{1}{c|}{ F } & Sig. \\
\hline 1 & Regression & 29,632 & 5 & 5,926 & 70,309 &, $000^{\mathrm{b}}$ \\
& Residual &, 927 & 11 &, 084 & & \\
& Total & 30,559 & 16 & & & \\
\hline
\end{tabular}

a. Dependent Variable: Performance

b. Predictors: (Constant), Gap_Technical, Gap_Leadership, Gap_Conceptual, Gap_Administrative, Gap_Interpersonal

Dari hasil pengujian hipotesis terlihat bahwa nilai $F_{\text {hitung }}$ sebesar 70,309 dengan tingkat signifikansi 0,000 , maka model regresi dapat dipakai untuk memprediksi bahwa terdapat hubungan signifikan antara variabel dependen (capaian kinerja operasional unit) dengan semua variabel independen (gap conceptual/creative, interpersonal, leadership, administrative, dan technical domain) secara bersamasama. Atau dengan kata lain, gap kompetensi dengan persepsi bawahannya menyangkut conceptual/creative, interpersonal, leadership, administrative, dan technical domain secara bersama-sama berpengaruh signifikan terhadap capaian kinerja operasional unit berupa customer complaint, delay, dan kecelakaan kerja.

Pengaruh variabel independen gap conceptual/creative, interpersonal, leadership, administrative, dan technical domain secara simultan terhadap capaian kinerja operasional unit dapat dilihat dari koefisien determinasi $\left(\mathrm{R}^{2}\right)$ sebagaimana tertera pada Tabel 4. di bawah ini:

\section{Tabel 4. Koefisien Determinasi}

\begin{tabular}{|c|c|c|c|c|}
\hline \multicolumn{5}{|c|}{ Model Summary } \\
\hline Model & $\mathrm{R}$ & R Square & $\begin{array}{l}\text { Adjusted R } \\
\text { Square }\end{array}$ & $\begin{array}{l}\text { Std. Error of } \\
\text { the Estimate }\end{array}$ \\
\hline 1 & $985^{\mathrm{a}}$ & 970 & 956 & 290327 \\
\hline
\end{tabular}

Berdasarkan hasil perhitungan sebagaimana ditunjukkan dalam Tabel 4.18. di atas, diperlihatkan nilai $\mathrm{R}^{2}$ sebesar 0,970. Dengan demikian dapat disimpulkan bahwa peran variabel 
independen bisa menjelaskan 97\% terhadap variasi variabel dependen. Sedangkan sisanya sebesar 3\% dijelaskan oleh faktor lain di luar model persamaan regresi.

\section{Pembahasan}

Hasil penelitian menunjukkan bahwa pada kelima dimensi pengukuran kompetensi karyawan tingkat struktural berdasarkan Sandwith's Competency Domain Model tidak ada perbedaan (gap) antara pengukuran kompetensi karyawan tingkat struktural dan persepsi bawahannya terhadap kompetensi atasannya tersebut. Pada domain pertama yaitu conceptual / creative competencies, dari hasil jawaban pertanyaan terbuka yang diajukan kepada karyawan tingkat struktural dalam kuesioner penelitian, untuk mengembangkan bisnis perusahaan beberapa orang menjawab (1) Membuat produk baru dengan membuat variasi menu baru yang lebih menarik, (2) Menjaga kualitas produk agar tetap baik sesuai standar yang telah ditetapkan perusahaan, (3) Membuat sistem terotomatisasi dari pekerjaan manual menjadi automatic, (4) Mengembangkan sistem pelayanan untuk mempertahankan customer,

Memperluas wawasan para karyawan di PT Aerofood Indonesia khususnya departemen produksi terutama hal yang terkait perkembangan bisnis di industri hospitality agar lebih mampu menghasilkan ide-ide baru untuk bersaing dengan kompetitor, dan (6) Melakukan kerja sama dengan perusahaan lain untuk mengadakan pelatihan.

Sedangkan untuk domain kedua yaitu interpersonal competencies, tidak adanya perbedaan nilai persepsi terkait kompetensi karyawan tingkat struktural antara karyawan tingkat struktural dan bawahannya adalah karena interpersonal competencies yang dimiliki oleh karyawan tingkat struktural diaplikasikan secara penuh kepada para bawahannya melalui kegiatan-kegiatan dalam masing-masing unit di departemen produksi PT Aerofood Indonesia. Kegiatan di departemen produksi yang secara tidak langsung meningkatkan interpersonal skills dari para atasan ini adalah (1) Briefing yang diadakan di awal memulai kegiatan setiap shift dan evaluasi yang dilakukan di akhir shift, (2) Adanya pelatihan-pelatihan dan seminar yang diadakan oleh departemen human resource (internal), (3) Sharing ilmu yang telah didapatkan atasan dari external training ke para bawahan, (4) Gathering karyawan seluruh unit di departemen produksi, dan (5) Pengambilan keputusan yang melibatkan serikat pekerja untuk menjaga hubungan baik dengan 
karyawan di seluruh unit di departemen produksi.

Selanjutnya, pada domain ketiga yaitu leadership competencies, dalam pertanyaan terbuka yang diajukan dalam kuesioner untuk karyawan tingkat struktural mengenai cara terbaik atasan dalam memberikan motivasi bagi para sesama rekan kerja dalam satu unit untuk mencapai pencapaian kinerja unit terdapat beberapa jawaban seperti (1) Memberikan apresiasi terhadap hasil kerja yang telah diberikan yang membawa kebaikan untuk perusahaan, (2) Menjaga hubungan komunikasi antar staff agar tetap kondusif dan kompak, (3) Melakukan Tour of Dutty, (4) Melakukan pendekatan secara personal dan instruksi langsung, (5) Memberikan kesempatan bawahan untuk mengikuti berbagai macam perlombaan kuliner, (6) Melakukan coaching untuk berdiskusi tentang pengalaman dan kesulitan yang dihadapi masing-masing karyawan, dan (7) Berperilaku yang baik sebagai contoh untuk bawahan.

Hasil penelitian juga menunjukkan tidak perbedaan (gap) signifikan antara pengukuran kompetensi karyawan tingkat struktural dan persepsi bawahannya terhadap kompetensi atasannya tersebut pada administrative domain dan technical domain karena perusahaan secara umum telah melakukan proses seleksi, standarisasi, pelatihan, dan peningkatan kapabilitas yang menjadi standar kompetensi karyawan yang bekerja di bidang jasa catering penerbangan. Sebagai perusahaan airline catering yang berskala internasional, PT Aerofood mengacu pada standar internasional layanan dan kompetensi jasa airline catering.

Hasil pengujian variabel independen berupa gap conceptual/creative, interpersonal, leadership, administrative, dan technical domain secara simultan terhadap capaian kinerja operasional unit memperlihatkan nilai $\mathrm{R}^{2}$ sebesar 0,970. Dengan demikian dapat disimpulkan bahwa peran variabel independen berupa gap kompetensi karyawan tingkat struktural dengan persepsi bawahannya tersebut bisa menjelaskan $97 \%$ terhadap variasi capaian kinerja masing-masing unit. Sedangkan sisanya sebesar 3\% dijelaskan oleh faktor lain di luar model persamaan regresi.

Aktivitas produksi yang dilakukan PT Aerofood Indonesia sebagai suatu perusahaan airline catering, sangatlah berbeda apabila diperbandingkan dengan perusahaan catering pada umumnya. Beberapa hal yang membedakan antara lain (1) Makanan yang disajikan akan dinikmati oleh konsumen akhir pada ketinggian tertentu dimana indera pengecap berkurang kepekaannya, 
Makanan dalam jumlah banyak harus telah siap dalam periode waktu cukup panjang dan melalui beberapa kondisi dan suhu sebelum siap terhidang untuk konsumen akhirnya, (3) Faktor keamanan dan keselamatan menjadi persyaratan utama suatu jasa penerbangan, (4) Kecepatan dan ketepatan waktu dalam melakukan offloading dan upload makanan keluar dan ke dalam pesawat menjadi standar layanan (service level agreement) yang harus dipatuhi secara ketat oleh perusahaan, (5) Perubahan siklus yang cukup cepat dan variasi menu beragam menuntut perusahaan melakukan perencanaan dan pengendalian secara ketat terhadap produksi, (6) Pelayanan kepada perusahaan penerbangan yang berpredikat "five star airlines" menuntut tingkat layanan (service level) katering penerbangan yang setara dengan kualitas bintang lima tersebut, dan (7) Lain-lain tentang unsur kreativitas serta layanan.

Domain conceptual-creative yang mengacu pada keahlian kognitif karyawan yang berkaitan dengan pemahaman elemen-elemen penting dari pekerjaan. Pemahaman atas peran supervisory di unit yang dipimpinnya serta kebergantungan keberhasilan pekerjaan dari kerjasama tim dilaksanakan dalam bentuk pertemuan dan briefing tentang pekerjaan yang akan dilakukan pada setiap mengawali shift.
Dalam briefing awal tersebut umumnya dibahas beberapa hal teknis operasional seperti (1) Mengingatkan dan pengendalian atas standar layanan serta kualitas yang menjadi outcome pekerjaan yang akan mereka lakukan, (2) Pembahasan komplain-komplain pelanggan (antara lain menyangkut adanya benda asing (foreign object) dalam makanan, makanan basi, ketidaksesuaian dengan makanan yang dipesan, ukuran/portion yang tidak sesuai, dan lain-lain), (3) Ketersediaan waktu dengan jumlah makanan yang harus disediakan dalam waktu tertentu, (4) Masukan dan kreatifitas karyawan dalam melaksanakan pekerjaannya, dan (5) Arahan mengenai kebijakan perusahaan.

Kompetensi kepemimpinan karyawan tingkat struktural yang terimplementasi secara efektif sehingga tidak menimbulkan perbedaan persepsi pada bawahannya memberikan hasil yang positif bagi pencapaian kinerja unit. Namun demikian dalam penelitian ini, perbedaan/gap kemampuan karyawan tingkat struktural menyangkut domain leadership dengan persepsi bawahannya, tidak berpengaruh secara signifikan terhadap pencapaian kinerja unit. Hal tersebut dimungkinkan karena sifat pekerjaan yang sangat teknis dan setiap karyawan mendapatkan pelatihan serta 
updating pengetahuan secara konsisten dan standar.

Kompetensi interpersonal berfokus pada keahlian untuk berinteraksi secara efektif dengan orang lain. Karyawan bidang produksi memiliki rincian tugas dan tanggung jawab masing-masing yang tersekat secara jelas dengan unit lainnya. Komunikasi dan interaksi dengan unit atau departemen lain dilakukan melalui mekanisme perencanaan yang jelas dan memiliki tenggat waktu serta standar kualitas sesuai bidang tugas masingmasing. Kemampuan supervisor atau karyawan tingkat struktural dalam berinteraksi secara efektif dengan karyawan stafnya dipandu melalui standar operating prosedur (SOP) yang baku. Secara parsial hasil uji regresi atas gap yang terjadi antara kemampuan interpersonal karyawan tingkat struktural dengan persepsi bawahannya tidak secara signifikan berpengaruh terhadap pencapaian kinerja unit.

Terkait gap antara kemampuan administratif dan technical domain dengan persepsi bawahan terhadap kompetensi tersebut akan berpengaruh secara signifikan terhadap pencapaian kinerja unit. Perbedaan persepsi antara aspek manajerial dan teknis yang dimaksudkan oleh karyawan struktural dengan bawahannya, akan berdampak langsung terhadap cara bagaimana karyawan staf tersebut melaksanakan pekerjaannya. Pada saat perbedaan persepsi terjadi, maka outcome yang dikehendaki oleh karyawan struktural terhadap tim kerjanya, tidak akan secara efektif tercapai.

\section{PENUTUP}

\section{Kesimpulan}

Secara keseluruhan terdapat dua hal yang dapat disimpulkan yaitu (1) Tidak ada perbedaan kompetensi karyawan tingkat struktural di Departemen PT Aerofood Indonesia terhadap persepsi bawahannya terkait conceptual / creative competencies, interpersonal competencies, leadership competencies, administrative domain dan technical domain atasannya serta (2) Terdapat pengaruh antara kompetensi karyawan tingkat struktural di Departemen Produksi PT Aerofood Indonesia dan persepsi bawahannya terkait tentang kompetensi para atasannya terhadap kinerja Departemen Produksi PT Aerofood Indonesia.

\section{Keterbatasan Penelitian dan Saran}

1. Kesulitan untuk mendapatkan jumlah dan keterwakilan sampel yang memadai, mengingat hampir seluruh karyawan unit produksi bekerja secara shift dan memiliki target pekerjaan yang sangat ketat.

Jurnal penelitian IImu Manajemen (JPIM) 
2. Tipe karyawan unit Produksi yang umumnya belum terbiasa menggunakan teknologi, menyebabkan pengisian kuesioner harus dilakukan dengan hardcopy dan tidak dapat menjangkau unit Produksi di lokasi operasional PT Aerofood di luar Jakarta.

3. Penelitian selanjutnya dapat memperluas cakupan penelitian dalam industri sejenis sehingga dapat dilihat perbandingan hasil pengukuran kompetensi untuk masing-masing perusahaan. Perluasan cakupan tersebut sekaligus untuk menguji apakah berbedaan budaya kerja dan sistem nilai/value turut berpengaruh.

4. Hasil penelitian di unit Produksi dapat digunakan untuk melakukan pengukuran kompetensi karyawan tingkat struktural di unit yang lain serta dapat memperlihatkan efektivitas human capital management system yang dilaksanakan di perusahaan.

\section{DAFTAR PUSTAKA}

Armstrong, Michael. (2009). ARMSTRONG'S HANDBOOK OF PERFORMANCE MANAGEMENT: An Evidence-based guide to delivering high performance. London: Kogan Page Limited.
Armstrong, M., \& Baron, A. (1998). Performance management: The new realities. State Mutual Book $\&$ Periodical Service.

Assauri, Sofjan. (1993). Manajemen Produksi. Edisi Ketiga. Jakarta: Lembaga Penerbit Fakultas Ekonomi Universitas Indonesia.

Bacal, R. (1999). Performance Measurement. Editorial.

Badan Pusat Statistik. (2015). Keadaan Angkatan Kerja. Jakarta: Badan Pusat Statistik.

Berger, L.A. \& Berger, D.R. (2008). Best Practices on Talent Management. Jakarta: PPM.

Budiharjo, Andreas. (2011). Organisasi: Menuju Pencapaian Kinerja Optimum. Jakarta: Prasetya Mulya Publishing.

Cho, S., Woods, R., Jang, S., \& Erdem, M. (2006). Measuring the impact of human resource management practices on hospitality firms' performances. International Journal of Hospitality Management, 262277.

Dessler, Gary. (2015). Manajemen Sumber Daya Manusia. Jakarta: Salemba Empat.

Dewi, Tris Susanti. (2012). Kompetensi Organisasi. 1 Februari 2017. http://www.hrcentro.com/artikel/Ko mpetensi_Organisasi_120515.html.

Gallardo-Gallardo, E., Dries, N., \& González-Cruz, T. F. (2013). What is the meaning of 'talent' in the world of work?. Human

Resource Management Review, 23(4), 290300.

Galloti, K. M. (2014). Cognitive Psychology In and Out the 
Laboratory. California: Sage Publications.

Hu, M. L. M. (2010). Developing a core competency model of innovative culinary development. International Journal of Hospitality Management, 29(4), 582-590.

Husein, Umar. (2003). Metodologi Penelitian Untuk Skripsi dan Tesis Bisnis. Jakarta: PT. Gramedia Pustaka.

Katz, R. L. (1955). Skills of an effective administrator. Harvard business review, 33(1), 33-42.

Kay, C., \& Russette, J. (2000). Hospitalitymanagement competencies: Identifying managers' essential skills. The Cornell Hotel and Restaurant Administration Quarterly, 41(2), 52-63.

Lilik Agung, A.M. (2002). Human Capital Competencies. Jakarta: Gramedia Group.

Lind, D.A., William G.M., \& Samuel A.W. (2010). Statistical techniques in business and economics. New York: McGraw-Hill.

Malhotra, Naresh K. (2010). Marketing Research an Applied Orientation. New Jersey: Pearson

Muhyi, D. H. A., Muttaqin, Z., Si, M., \& Healthy Nirmalasari, M. B. A. $H R$ PLAN \& STRATEGY: Strategi Jitu Pengembangan Sumber Daya Manusia. RAIH ASA SUKSES.

Noe, Raymond A, et al. (2008). Human Resources Management: Gaining a Competitive Advantage. $4^{\text {th }}$ edition. New York: McGraw-Hill/Irwin.

Otara, A. (2011). Perception: A Guide for Managers and Leaders. Journal of Management and Strategy, 2 (3), 2124.
Parmenter, D. (2010). Key Performance Indicators: Developing, Implementing, and Using Winning KPIs, 2nd edn. Jon Wiley \& Sons.

Koenigsfeld, J., Perdue, J., Youn, H., \& Woods, R. H. (2011). The changing face of competencies for club managers. International Journal of Contemporary

Hospitality Management, 23(7), 902-922.

Permana dkk. (2011). TALENT MANAGEMENT

IMPLEMENTATION: Belajar dari Perusahaan-Perusahaan Terkemuka. Jakarta: PPM

Pratten, J. (2003). The training and retention of chefs. Int J Contemp Hospitality Mngt International Journal of Contemporary Hospitality Management, 237-242.

Quick, J.C., Nelson, D.L. (2009). Principles of Organizational Behavior $6^{\text {th }}$ Edition. California: South Western College.

Rampersad, H. K. (2006). Personal Balanced Scorecard: The Way to Individual Happiness, Personal Integrity, and Organizational Effectiveness;[foreword by Jeannette Lee]. IAP.

Sabuncu, K. U., \& Karacay, G. (2016). Exploring Professional Competencies for Talent Management in Hospitality and Food Sector in Turkey. Procedia-Social and Behavioral Sciences, 235, 443452.

Sandwith, P. (1993). A hierarchy of management training requirements: The competency domain model. Public Personnel Management, 22(1), 43-62. 
Slovin, M. J. (1960). Sampling. New York: Simon and Schuster Inc.

Smilansky, Jonathan PhD. (2006). Developing Executive Talent: Best Practices from Global Leaders. New York: AMACON.

Spencer, L. M. (1993). Competence at Work: Models for Superior Performance. Kanada: John Wiley and Sons.

Sugiyono. (2010). Metode Penelitian Pendidikan Pendekatan Kuantitatif, kualitatif, dan $R \& D$. Bandung: Alfabeta

Tas, R. E., LaBrecque, S. V., \& Clayton, H. R. (1996). Property-management competencies for management trainees. The Cornell Hotel and Restaurant Administration Quarterly, 37(4), 90-96.

Tsai, F.C., Goh, B.K., Huffman, L. and Wu, C.K. (2006), "Competency assessment for entry-level lodging management trainees in Taiwan", The Chinese Economy, Vol. 39 No. 6, pp. 49-68.

Usman, Husaini \& Akbar, Purnomo Setiady. (2008). Metodologi Penelitian Sosial. Jakarta: PT. Bumi Aksara

Wellins, et. al. (2010). Nine Best Practices For Effective Talent Management. Development Dimensions International.

Wenats, AG Eka. (2012). Integrated Marketing Communications Success Story. Jakarta : PT. Gramedia Pustaka Utama.

Widagdo, R. (2016). Faktor Internal Produksi Dan Pengaruhnya Dalam Perkembangan Usaha Atau Industri. Al Amwal, 6(1). 